\title{
Understanding the governance dynamics of a supranational university: The African pioneering model
}

\author{
Lazarus Nabaho, Wilberforce Turyasingura, Jessica Norah Aguti, \\ and Felix Adiburu Andama*
}

doi: http://dx.doi.org/10.18543/tjhe-8(1)-2020pp27-52

Received: 4 May 2020

Accepted: 29 July 2020

\begin{abstract}
Since the 1990s, university governance has attracted the attention of scholars. However, most of the extant studies focus on the governance of nationallevel universities and use national regulatory frameworks. Therefore, there is a dearth of studies that hinge on the governance of supranational higher education institutions, such as the Pan African University (PAU), with the aid of regional regulatory frameworks. Consequently, little is known about the governance architecture of supranational universities, which are a post-2010 phenomenon. In view of the above, the article answers the following question: How is the Pan African University governed within a multi-layer environment? Using an interpretive lens, data was collected from the Revised Statute of the Pan African University, 2016. Content analysis was used to analyse the resultant data. The findings revealed that observance of the values of higher education, adoption of the steering-at-a-distance university governance model by the African Union Commission and of the shared governance arrangement, and merit-based selection of staff are the hallmarks of the PAU governance architecture. The governance model of the PAU resonates with the governance architecture of country-level universities in form rather than in substance. The notable variations in the substance include the partial adoption of the philosophy of 'letting the managers manage', the existence of multi-governance layers, lay
\end{abstract}

* Lazarus Nabaho (lnabaho@umi.ac.ug), PhD in Education Management, is a Senior Lecturer and the Head of the Department of Government Studies at Uganda Management Institute, Uganda.

* Wilberforce Turyasingura (wturyasingura@umi.ac.ug), PhD in Management, is the Dean of the School of Business and Management at Uganda Management Institute, Uganda.

* Jessica Norah Aguti (aguti@cees.mak.ac.ug), PhD in Curriculum Instruction and Teaching, is an Associate Professor in the Institute of Open, Distance \& e Learning, Makerere University, Uganda.

* Felix Adiburu Andama (fandama@umi.ac.ug), PhD in Governance and Public Sector Management, is a Consultant in Government Studies at Uganda Management Institute.

More information about the authors is available at the end of this article. 
domination of the University Senate, the presence of 'universities' in PAU governance arrangement, the existence of a 'quasi-governance' organ with external representation at the level of the Institute, and the continental outlook of the PAU Council. Therefore, it can be concluded that the missions of the universities and their context shape universities' governance architecture.

Keywords: Governance; university; supranational; organs; functions; Pan African University.

\section{Introduction}

University governance is top of the agenda of the stakeholders in higher education across the globe. The extant studies demonstrate that it is a sine qua non for the performance of universities ${ }^{1}$ and, specifically, the "financial, research and teaching performances."2 University governance, when viewed through the prism above, provides an enabling environment for the effective execution of the teaching, research and community engagement missions of the academe. The nexus between university governance and university effectiveness, coupled with the shifting roles of universities in society, has ignited the search for appropriate models of university governance.

Since the 1980s, as a result of the transnational ideas of New Public Management (NPM), university governance in both developed and developing countries has undergone an unprecedented wave of reforms. The first casualty of the NPM-inspired governance reforms was the collegial (or traditional) model of university governance. The model was considered inappropriate in the light of the post-1980 global higher education landscape, which dictated more flexible and external environment-responsive governance arrangements. ${ }^{3}$ A central attribute of the collegial model of university governance was that the university Senate, which comprised the professoriate, was the pinnacle of power and authority in the university. ${ }^{4}$ For

${ }^{1}$ Javier Núñez and Benjamin Leiva, "The effects of a tripartite 'participative' university senate on university governance: the case of the University of Chile," Cambridge Journal of Education 48, no.6 (2018): 749.

${ }^{2}$ Chitra Lokuwaduge and Anona Armstrong, "The impact of governance on the performance of the higher education sector in Australia," Education Management, Administration and Leadership 43, no.5 (2014): 822.

${ }^{3}$ Mark Taylor, "Shared governance in the modern university," Higher Education Quarterly 67, no.1 (2013): 91.

${ }^{4}$ Julie Rowlands, Academic governance in the contemporary university: Perspectives from Anglophone nations (Singapore: Springer, 2017): 27. 
example, in civic universities in the United Kingdom- prior to the 1980s"no governing body would act in a major policy issue without consulting the Senate and most policy issues were in practice initiated at the senate level." 5 The status of the university Senate in governance was reinforced by the prevailing notion in universities that none other than the academics were "sufficiently qualified to regulate the public affairs of scholars." ${ }^{6}$ One of the hallmarks of the collegial model of university governance was that the Vice Chancellors (or the Rectors) were elected by the Senate from among the professors- as the first among equals- to execute a range of ceremonial and administrative duties. ${ }^{7}$ The collegial model was criticised, inter alia, for its inward-looking inclination and fascination with the status quo, the sluggishness in responding to the rapidly changing external environment owing to the consensus-building norm through committees ${ }^{8}$ as well as the perpetual obstructionist tendencies of academics. ${ }^{9}$

Therefore, the collegial model had to pave way for the emergence of a corporate model of governance that is common in the business world. The corporate model of governance - or the entrepreneurial model- is reinforced by the NPM ideas that regard business models as "superior in terms of assuring greater efficiency, accountability, and more effective in managing financial and human resources." 10 The adoption of the corporate model necessitated shifting power away from the senates to new structures (or University Councils) which are lay-dominated, strengthening the institutional leadership ${ }^{11}$ as well as reconfiguring the role of the Senate from "decision

5 Michael Shattock, "The context of 'modernising' reforms in university governance," in International trends in university governance, ed. Michael Shattock (Oxford: Routledge, 2014).

${ }^{6}$ Graeme Moodie and Rowland Eustace. Power and authority in British universities (London: Allen and Unwin, 1974).

7 William Saint, "Guiding Universities: Governance and Management Arrangements Around the Globe" (2009): 2.

8 James J. Duderstadt, "Governing the twenty-first century university: A view from the bridge" (2002), accessed April 1, 2020, milproj.ummu.umich.edu/publications/view_from_ bridge/.../view_from_bridge.pdf.

9 Robert Birnbaum, "The end of shared governance: Looking ahead or looking back," New Directions for Higher Education 127(2004): 6.

${ }^{10}$ Kay Harman and Elaine Treadgold, "Changing patterns of governance for Australian universities," Higher Education Research \& Development 26, no.1 (2007): 13.

${ }^{11}$ Michael Shattock, "University governance, leadership and management in a decade of diversification and uncertainty," Higher Education Quarterly 67, no.3 (2013): 221. 
making to advisory functions" 12 save on pure academic questions. Furthermore, the advent of the corporate model occasioned a shift in power from the academic community towards the executive leadership team headed by the Vice Chancellor ${ }^{13}$ as the chief executive officer (CEO).

The NPM-inspired reforms equally induced a transformation from the direct methods of steering universities by governments to indirect methods of steering through the University Councils which are anchored in the maxim of less government and more governance. This migratory trend in university governance has been assigned the label 'steering at a distance' or 'selfgovernance' and is associated with the rise of the Evaluative State. ${ }^{14}$ Steering universities, and, therefore, higher education, at a distance marks a departure from the classical State control to the State supervision model. Under steering higher education at a distance, the Evaluative State "steers higher education towards what it perceives the market needs" 15 with less reliance on legal procedures. Within the new steering mode, the Evaluative State employs contemporary instruments - such as "funding allocation, evaluation and accreditation procedures, human resources policy, and institutional governance structures"16 - that shape the overall strategy of the university. The common elements of the post-1980 university governance reforms constellate around "the enhancement of institutional autonomy, the professionalization of institutional leadership and administration, and the introduction of more competitive, performance-oriented funding models." ${ }^{17}$

Since the 1990s, studies on university governance have burgeoned in both developed and developing countries. These studies hinge on countrylevel governance reforms that have impacted higher education institutions in the national higher education landscapes. Relatedly, the studies examine the governance arrangements in universities using the national policy and legal frameworks, regulations and guidelines. Other studies have examined

${ }_{12}$ Ivar Bleiklie, "Collegiality and hierarchy: Coordinating principles in higher education," in The global university: Past, present and future perspectives, edited by A. R. Nelson and I. P. Wei (New York, NY: Palgrave Macmillan, 2012): 90.

${ }_{13}$ Marginson Simon and Considine Mark, The enterprise university (Melbourne: Cambridge University Press, 2000).

${ }^{14}$ Guy Neave, "The Evaluative State reconsidered," European Journal of Education 33, no.3 (1998): 274.

${ }_{15}$ Neave, "The Evaluative State reconsidered", 277.

16 Davide Donina and Sandra Hasanefendic, "Higher Education institutional governance reforms in the Netherlands, Portugal and Italy: A policy translation perspective addressing the homogeneous/ heterogeneous dilemma, "Higher Education Quarterly 73 (2019):30.

17 Åse Gornitzka, Peter Maassen, and Harry de Boer, "Change in university governance structures in continental Europe,” Higher Education Quarterly 71(2017): 274. 
university governance from a supranational viewpoint and, specifically, in the European Higher Education Area - an outcome of the Bologna Declaration of 1999. Nevertheless, these studies boil down to the State level and interrogate how the Bologna Process has influenced the governance architecture at the national level. Consequently, there is a dearth of studies that lean towards the governance of supranational higher education institutions such as the Pan African University (PAU) using regional regulatory instruments. This shortage of scholarship is not unexpected because the concept of supranational universities is new in the global higher education landscape. While Africa actualised the vision of a continental university in 2010-the PAU -, the European Universities idea is already at the project stage. ${ }^{18}$ A supranational university - by virtue of its collective ownership by independent States, configuration along thematic areas, the presence of their Institute in national higher education spaces, and its transnational mandate may necessitate context-sensitive governance arrangements. Therefore, a one size-fits-all governance architecture may be inappropriate for the new genre of universities in the higher education landscape. The dearth of studies on this category of universities means that little is known about such governance architecture for supranational universities.

Against the above background, this article answers the following question: How is the PAU governed within a multi-layer environment? This article comprises five sections. The literature review section follows this introductory section. This is followed by the results section and the discussion and conclusions section, respectively.

\section{Literature review}

This section unpacks and examines university governance in general and further highlights the evolution, mandate and organisation of the PAU.

\section{II.1. Conceptualisation of university governance}

University governance defies a single definition and it is, therefore, not surprising that it has been assigned the tag of an ambiguous and highly

18 Brendan O’Malley, "First 17 European universities' alliances announced," World News, $27^{\text {th }}$ June 2019, accessed $3^{\text {rd }}$ April 2020, https://www.universityworldnews.com/post. php?story $=2019062708524036$. 
contested concept in higher education discourse. Generally, governance has been associated with basic terms such as 'steering', 'directing' and 'guiding'. ${ }^{19}$ In a broad sense, "... governance is about power and authority, who has it and who does not and in whose interest it is used" 20 and also a matter of "responding to the question: who makes what decisions?"21 Beyond the general conceptualisations, OECD defines university governance as "the structures, relationships and processes through which, at both national and institutional levels, policies for tertiary education are developed, implemented [and reviewed]." ${ }^{22}$ University governance is also unravelled as "a conceptual shorthand for the way higher education...institutions are organised and managed." ${ }^{23}$ From the above definitions, it can be argued that any attempt to arrive at a solitary definition of university governance is akin to attempting to hit a moving target. However, we find the definition by OECD more appealing because the alternative definitions are implied in it. For example, power, authority, and decision-making which feature in the other definitions are exercised within the structures, relationships and processes which are apparent in the OECD's definition. Finally, the structures and processes in OECD's definition are implied in Neave's definition. The absence of a unified definition notwithstanding, both practitioners and the academia concur that " $[\mathrm{g}]$ overnance has become a major leverage tool for improving quality in all aspects of higher education." ${ }^{24}$

The World Bank provides two broad categories of (university) governance: external governance and internal governance. Within this classification, external governance connotes "relations between institutions and their supervisors", whereas internal governance hinges on "lines of authority within institutions." ${ }^{25}$ Despite the overlaps between governance

${ }^{19}$ Bob Jessop, "The rise of governance and the risks of failure: The case of economic development," International Social Science Journal 155 (1998): 30.

${ }^{20}$ Kerry J. Kennedy, "Higher education governance as a key policy issue in the $21^{\text {st }}$ century," Educational Research for Policy and Practice 2, no.1 (2003):67.

${ }_{21}$ Toma, J. Douglas, "Expanding peripheral activities, increasing accountability demands and reconsidering governance in US higher education," Higher Education Research and Development 26, no.1 (2007): 57.

${ }^{22}$ OECD, "OECD thematic review of tertiary education," (2008), accessed $14^{\text {th }}$ March 2020, http://www.oecd.org/education/skills-beyond-school/37524697.pdf.

${ }^{23}$ Guy Neave, "Governance, power and coordination," IAU Horizons 12, no.1 (2006): 4.

${ }^{24}$ Fabrice Hénard and Alexander Mitterle, Governing and quality guidelines in higher education: A review of governance arrangements and quality assurance guidelines (OECD, 2009): 15.

${ }^{25}$ World Bank, Higher education in developing countries: Peril and promise (Washington, DC: The World Bank, 2000). 
and management, attempts have been made to draw a dividing line between the two concepts. Whereas governance is concerned with the formulation of policies, management has to do with "the implementation and execution of policies." 26

There has been a burgeoning in literature on university governance in Africa. However, as mentioned earlier, the extant literature is skewed towards the governance of public and private universities in national higher education spaces. There is a dearth of studies on the governance of supranational universities using international regulatory frameworks.

The African Standards and Guidelines for Quality Assurance in Higher Education (ASG-QA), which have been in operation since 2018, provide anecdotal insights into the minimum governance architecture of the PAU owing to its continent-wide application. The ASG-QA comprise "governance and management" as one of the 13 standards for African higher education. ${ }^{27}$ The ASG-QA stipulate that every higher education institution in the African higher education landscape should have the "...[the] relevant governance and management bodies, such as the University [or Governing] Council, Senate, Management Board, Student Body; and various committees, each with a clear mandate, duties, responsibilities, powers, privileges and tenure" 28 The ASG-QA underscore the imperative to have a competent leadership and management and to provide for student representation in the governance organs..$^{29}$

However, the ASG-QA do not portray the entire picture of the governance arrangements of universities, and especially for a supranational university such as the PAU. Rather, they provide the minimum standards rather than a common template. While the existence of the governance organs is mandatory, the assignment of responsibilities to the governance organs as well as the modus operandi of filling the organs are at the discretion of the African Union Commission (AUC) - in the case of the PAU- and the various national jurisdictions. Therefore, a plethora of pertinent questions regarding the governance of the PAU remain unanswered. For example, issues such as these remain unclear: whether the university functions under a unicameral,

${ }^{26}$ World Bank, "Higher education in developing countries," 59.

${ }^{27}$ Lazarus Nabaho et al., "Quality Assurance of Higher Education Governance and Management: An Exploration of the Minimum Imperative for the Envisioned African Common Higher Education Space," Higher Learning Research Communications 10, no.2 (2020): 40.

${ }_{28}$ African Union Commission, African Standards and Guidelines for Quality Assurance in Higher Education (Addis Ababa: African Union, 2018).

${ }_{29}$ Nabaho et al., "Quality Assurance," 44-47. 
bicameral or tricameral model; whether the Senate has advisory or decisionmaking powers; and the composition of the governance organs.

\section{II.2. The Pan African University (PAU)}

The idea of a continental university was conceptualised in 2008 within the Plan of Action for the Second Decade of Education for Africa (20062015). The idea finally became a reality in 2010 when the PAU was established by the African Heads of State and Government. The PAU was launched by the AUC on 14 December 2011 as a flagship continental initiative. The headquarters of the PAU is in Yaoundé, Cameroon. The PAU is a continental postgraduate academic, research and innovation institution that was established to invigorate African higher education and research as well as to produce highly skilled knowledge workers to promote the region's knowledge-driven economic growth and development.

The PAU is not a completely new higher education institution but rather a network of existing African universities operating at graduate level in the different regions of the continent. The University comprises five thematicbased Institutes located in the five regions of Africa. The thematic areas are water and energy sciences (including climate change); basic sciences, technology and innovation; life and earth sciences; governance, humanities and social sciences; and space sciences. The thematic-based Institutes of the PAU are:

a. The PAU Institute for Water and Energy Sciences at the University of Tlemcen, Algeria, in the Northern Africa region;

b. The PAU Institute for Basic Sciences, Technology and Innovation at the Jomo Kenyatta University of Agriculture and Technology, Kenya, in Eastern Africa;

c. The PAU Institute for Life and Earth Sciences at the University of Ibadan (Nigeria) in Western Africa;

d. The PAU Institute for Governance, Humanities and Social Sciences at the University of Yaoundé 11 (Cameroon), in Central Africa; and

e. The PAU Institute for Space Sciences (South Africa) for Southern Africa, to be hosted by the Cape Peninsula University.

The African Virtual and E-University, which appears in Agenda 2063 as a flagship project of the African Union, "was realigned by the Executive Council in January 2018 to be operationalized as the open, distance and 
e-learning arm of PAU" ${ }^{\prime 30}$ and was launched on 20 December 2019. It aims at "[i]ncreasing access to tertiary and continuing education in Africa by reaching large numbers of students and professionals in multiple sites simultaneously." 31

\section{Methods}

The article explored a particular educational phenomenon - the governance of a supranational university that is characterised by sparse configuration of constituent Institutes. In line with exploratory enquiries, the article employed an interpretive lens. Document review was the sole data collection method. The data was extracted from the Revised Statute of the Pan African University, 2016. The Statute was adopted by the $26^{\text {th }}$ Ordinary Session of the Assembly held on 31 January 2016 in Addis Ababa, Ethiopia. The Revised Statute articulates the collective thinking of the Heads of State and Government of the African Union (AU) or the Assembly in terms of how the PAU should be steered. Most of the Articles of the Statute hinge on governance and management. The following information was extracted from the Statute:

a) The principles that underpin the governance of the university

b) The governance organs

c) The responsibilities assigned to the governance organs

d) The mode of filling the governance organs

e) The relationship between the PAU, the AUC and the host universities of the PAU Institutes

Content analysis - "a research technique for making replicable and valid inferences from text (or other meaningful matter) to the contexts of their use" 32 - was employed to make sense of the data. The data analysis process commenced with writing headings and notes in the Revised Statute while reading it. The notes were used to identify categories from which the themes were developed.

${ }^{30}$ Pan African University, Strategic Plan (2020-2024) (Yaoundé: PAU, 2020): 6.

31 African Union Commission, Agenda 2063: First Ten Year Implementation Plan 20142023 (Addis Ababa: AUC, 2015): 4.

${ }^{32}$ Klaus Krippendorff K., Content analysis: An introduction to its methodology, 2nd ed. (Thousand Oaks: Sage, 2004): 18-19. 


\section{Results}

This section presents the findings on the governance arrangement of the PAU. The results are presented according to the themes that were extracted from the legal instrument that established the University. The salient and multi-faceted features of the University's governance are represented in the themes below.

\section{IV.1. Observance of the values of higher education}

Higher education, as a sub-sector of the education system(s), has a common set of values: academic freedom, autonomy and accountability. However, these values may not be entrenched in all the higher education systems. Some States- and even higher education institutions- can transgress the values of higher education. Similarly, the degree of observance of the values can vary from one higher education space to another and from one university to another, depending on the context.

The three values of higher education are part of the principles of the PAU in the Revised Statute, 2016. The Statute confers academic freedom upon the PAU. The Statute is cognisant of the potential of the PAU, the host countries and the host universities of the PAU (and its Institutes) to suffocate academic freedom. To militate against any likely assault on academic freedom, the regulatory framework stipulates that "[t]he PAU as well as its host countries and the host universities shall grant full academic freedom and selfgovernance in teaching and research to all members of the academic and research staff of the University." 33

As far as institutional autonomy is concerned, the Statute categorises the PAU as "an autonomous institution of the African Union." ${ }^{34}$ By implication, the PAU is a self-governing entity of the AU and, therefore, operates at armchair length from the AUC. The self-governing status accords the PAU the latitude, within the broad frameworks of the AUC, to do the following: formulate the staff regulations and rules; determine the university structure; recruit staff; discipline staff; manage finances; determine the research priorities; formulate and operationalise policies pertaining to teaching, research and innovation; and decide what to teach and who to teach it.

${ }_{33}$ African Union Commission, Revised Statute of the Pan African University (Addis Ababa: AUC, 2016): 4.

${ }^{34}$ African Union Commission, "Revised Statute," 5. 
Accountability by the PAU is apparent in the Statute as a principle of the PAU - as an obligation of the PAU Council. As such, it has an implication for the governance organs as the substitute for AUC's control of the PAU. The Revised Statute is explicit on accountability as a guiding principle of the PAU. As a statutory obligation, the PAU Council is required under the Revised Statute to "[r]eport annually on the work of the PAU to the African Union Assembly." ${ }^{35}$ In governance and management, reports constitute an accountability tool; they communicate what has been done, how it was done, and what has not been done and why it was not done. Structurally, the PAU Council is positioned between the Assembly at the helm and the University at the bottom. Using the scalar chain principle, it can be inferred that the Rectorate is responsible to the PAU Council which is, in turn, accountable to the Assembly.

The three values (academic freedom, autonomy and accountability) of the PAU are not an end in themselves and the AU Assembly did not entrench them in the Revised Statute in a vacuum. The legal framework stresses a direct nexus between these values and the realisation of the demanding objectives of the PAU. Therefore, the Statute considers these virtues a prerequisite for the supranational university to "function under the best attainable conditions and standards." ${ }^{36}$

\section{IV.2. Adoption of the steering-from-a-distance principle}

It is explicit that the AUC has granted operating space to the PAU. The granting of autonomy to the PAU under the Revised Statute is the first attestation to the AUC's resolve to steer the University from a distance. Therefore, attempts to micro-manage the University can be construed as observance of the virtue of institutional autonomy more in breach than in practice. However, steering the University from a distance ought to transcend mere articulation of the principles of the University in legislative instruments. The governance architecture should be sensitive to the espoused principles. A mismatch between the values and the structure would amount simply to political symbolism. The governance organs of the PAU depict the congruence between the value of institutional autonomy and the principle of steering at a distance. The Assembly of the African Union - a grouping of the Heads of State and Government- undertook to steer the PAU at a distance by

\footnotetext{
${ }^{35}$ African Union Commission, "Revised Statute," 8.

${ }^{36}$ African Union Commission, "Revised Statute," 5.
} 
entrenching the PAU Council in the Revised Statute. Under the direct steering of the University- the opposite of steering from a distance- the PAU Council would be a misplaced governance organ. The PAU Council is an intermediate organ between the Assembly, which has the "supreme overall responsibility of overseeing the PAU" ${ }^{37}$ and the PAU. Within the concept of institutional autonomy, the PAU Council is a buffer organ upon which falls the de facto onus to shield the senior management against excessive political interference.

The Revised Statute is implicit on the AUC's alternative instruments for steering the PAU at a distance. The first instrument is the Revised Statute itself. The Statute delineates what the University and the university governance organs can do and cannot do on matters relating to the operations of the University. For example, the teaching and research activities of the PAU should strictly align with the thematic areas which the AUC deems critical to Africa's development. Secondly, an Institute of the PAU is implicitly curtailed from designing and implementing programmes as well as conducting research that does not fall within the approved thematic area. As far as quality assurance is concerned, the steering instruments feature in the Revised Statute alongside other principles of the PAU. Within the quality assurance domain, the AUC is progressing towards establishing an African (Higher) Accreditation Agency. ${ }^{38}$ As with the practice at national level where national accreditation agencies have been established, the agency will steer the PAU through, among others, ex post programme accreditation and external evaluation or quality audit. Specifically, accreditation will gauge the academic programmes of the PAU and other universities, and the extent to which they align with the theme which has been assigned to the Institute. Finally, as in national jurisdictions, the accreditation agency will be responsible for supervising the PAU. We should add a caveat here: the agency will have a continent-wide mandate over higher education in Africa and, by implication, all higher education institutions. Generally, these instruments are intended to influence the PAU to be sensitive to Africa's development priorities and to view herself as a means to an end- a tool for the realisation of the AU's long-term vision.

37 African Union Commission, "Revised Statute," 7.

${ }_{38}$ African Union Commission, Agenda 2063: The Africa We Want (Addis Ababa: AUC, 2015). 


\section{IV.3. Observance of the shared governance model}

The shared governance (and management) architecture of the PAU can be examined from two levels: the University-level governance arrangement and the Institute-level management arrangement.

IV.3.1. University-level governance architecture

Governance at the University level follows the tripartite model that assigns responsibilities to the triple governance organs of the academy: the University Council, the University Senate, and the Rectorate.

\section{IV.3.1.1. The PAU Council}

The PAU Council is the supreme governing organ of the PAU. Supremacy in this case suggests that it has the final say on all the affairs of the University save for purely academic questions. The legal framework for the PAU stipulates, inter alia, the functions and composition of the PAU Council. The primary responsibilities of the PAU relate to approving the recommendations from the PAU Senate and the Rectorate. The word "approval" appears in eight out of the 12 functions of the PAU Council. The matters for approval by the PAU Council can be nested into two categories: academic matters and administrative matters:

\section{Table 1}

Business for approval by the PAU Council

\begin{tabular}{|c|c|}
\hline $\begin{array}{l}\text { Business from Senate for approval } \\
\text { by the PAU Council }\end{array}$ & $\begin{array}{l}\text { Business from the Rectorate for approval } \\
\text { by the PAU Council }\end{array}$ \\
\hline $\begin{array}{l}\text { - Recruitment, promotion and } \\
\text { discipline of academic and } \\
\text { research staff } \\
\text { - General staff rules and } \\
\text { regulations, taking into } \\
\text { account the recommendations } \\
\text { from the PAU Senate } \\
\text { regarding regulations related } \\
\text { to the recruitment and } \\
\text { selection of academic staff } \\
\text { - Code of conduct for PAU staff } \\
\text { and students }\end{array}$ & $\begin{array}{l}\text { - All other PAU regulations, rules, } \\
\text { measures, directives, policies and } \\
\text { procedures which shall govern the } \\
\text { activities of the PAU } \\
\text { - Work plans and budgets } \\
\text { - Strategic development plans and } \\
\text { operational plans } \\
\text { - Agreements, contracts and other } \\
\text { arrangements of a legal nature to be } \\
\text { signed by the Rector on behalf of the PAU } \\
\text { - Appointment of members of the PAU } \\
\text { Senate nominated by the Rector }\end{array}$ \\
\hline
\end{tabular}


Three extrapolations can be made from the foregoing discourse. First, the PAU has been assigned a general supervisory role, as exemplified by most of its business originating from the lower-level governance organs. Second, decisions of the PAU Senate which have financial implications (e.g. recruitment, promotion and discipline of academic and research staff) and a regulatory component require approval by the PAU Council. The regulatory aspects include policies, rules and regulations, codes of conduct, and guidelines. Therefore, the PAU Senate functions as a committee of the PAU Council on matters that require approval by the latter. Despite functioning as a committee, the PAU Council cannot act on such matters without recommendations from the PAU Senate. Finally, in a few instances the PAU Council has jurisdiction to act in some matters without recommendations from the PAU Senate but is only required to consult it. A review of the functions of the PAU Council reveals that decisions of the PAU Council which have academic implications (e.g. designating new Centres of the PAU and Institutions affiliated to the PAU as well as Programme Departments within the Institutes and Centres of the PAU) require consultation with the Senate.

However, it should be borne in mind that the PAU Council does not have absolute powers over the approval of the staff rules and regulations. This is a case where 'approval' requires 'approval' by another authority. After approval by the PAU Council, the staff rules and regulations are submitted to the Executive Committee of the AU for final approval. This requirement that the PAU Staff rules and regulations should be approved by the Executive Council is precautionary in nature and a risk-prevention and management strategy. In other words, it is intended to guard against the PAU Council varying the staff rules and regulations from the Staff Rules and Regulations of the African Union, which equally apply to staff of the PAU. However, this does not mean that the PAU's role to develop staff rules and regulations is completely curtailed. The PAU can, in fact, develop staff rules and regulations on human resource management aspects which the Statute has declared in the AUC Staff Rules and Regulations as not applicable to the PAU academic staff. These include the provisions of the AU Staff Rules and Regulations on age and the quota system as well as "other exceptions as may be identified taking into account the unique nature of the PAU as an academic institution" 39 and which must be submitted "for the consideration and approval of the Executive Council." 40

\footnotetext{
39 African Union Commission, "Revised Statute," 20.

40 African Union Commission, "Revised Statute," 20.
} 
The PAU Council comprises:

- [The] President;

- [The] Vice President;

- The Commissioner for Human Resources, Science and Technology;

- The Vice Chancellors/Vice Rectors of all host universities of PAU Institutes;

- The Chairperson of the Specialised Technical Committee (STC) in charge of education or his/her representative;

- The PAU Rector (ex-officio);

- The Directors of all PAU Institutes;

- A representative of the United Nations Educational, Scientific and Cultural Organisation (UNESCO);

- A representative from each of the RECs [Regional Economic Communities];

- Two scholars from the African Diaspora appointed by the Chairperson of the Commission;

- A representative of the Association of African Universities (AAU);

- A representative of the African Academy of Sciences (AAS);

- A representative of the Key and Thematic Partners on a rotational basis;

- A representative of academic staff of the PAU;

- A representative of administrative staff of the PAU; and

- Two representatives of students of the PAU.

The composition of the PAU Council, except for the President and Vice President, is both representational (constituency-based) and position-based. The majority of the members of the PAU Council represent a section of stakeholders while others qualify for membership by virtue of the positions they hold in the AUC, and in the host universities or the PAU. The President and Vice President of the PAU Council are not elected from among the members of the PAU Council. Rather, they are elected by the Executive Council from a list of five candidates presented by the Bureau of the Specialised Technical Committee (STC) of the AU. The Executive Council comprises the Ministers responsible for foreign affairs of the member States of the AU while an STC is a thematic committee on education, science and technology that is answerable to the Executive Committee. The STC on Education, Science and Technology brings together the Ministers in charge of education, and the Ministers in charge of science, technology and innovation. Therefore, the President and Vice President of the PAU are 
indirect representatives of the AU on the PAU Council. The mode of appointment of the leadership of the PAU could have been intended to provide the leaders with the authority to promote the continental interests as opposed to narrow constituency-based interests. Second, it could have been intended to forestall the risk of breeding incompetent leadership of the oversight organ, which can arise if the leadership is selected from among the members.

The composition of the PAU Council stresses two messages. First, the University should be viewed through the lens of a stakeholder organisation rather than a closed community of scholars. Within the stakeholder discourse, both internal and external stakeholders should be involved in university governance. Despite this, the PAU Council is lay-dominated. This is attested by the two-thirds (or 20) of the members of the PAU who are neither employees of the PAU nor students. The decision-making processes of the PAU can shed some light on what is beneath these numbers. Operationally, the decisions of the PAU Council are adopted by a two-thirds majority of the members present. Therefore, tilting the numerical strength of the PAU Council in favour of lay people could have been meant to avert the internal stakeholders' obstructionist tendencies as far as decision-making on matters that are diametrical to their interests is concerned. The second message is the imperative to strengthen linkages between the University and society.

The PAU Council has very high prospects of attracting over $50 \%$ of persons who have either toiled or are toiling in the vineyard of teaching and research. The obvious cases are the five Vice Chancellors of the host universities, the Rector of the PAU, the five Directors of the PAU Institutes, two scholars from the African Diaspora, the representative of the academic staff of the PAU, and a representative of the Association of African Universities. This brings the number to 15 out of the 30 members. This is arguably one strength of the PAU Council. Such an oversight body is likely to be predisposed towards matters of education policy rather than the general administrative matters and is likely to rely less on the strategic guidance of the Rector.

\section{IV.3.1.2. The Senate}

The PAU Senate is responsible for the "academic affairs, research and innovation activities of the PAU" ${ }^{41}$ as well as the welfare of students. It is the principal academic body of the PAU. The PAU Senate has a broad range of

${ }^{41}$ African Union Commission, “Revised Statute," 12. 
advisory responsibilities to the PAU as well as a narrow scope of decisionmaking responsibilities. The advisory roles relate to making recommendations to the PAU Council on the matters that have been highlighted in the first column of Table 1 above. The decision-making responsibilities of the PAU Senate hinge on purely academic matters such as "admission, assessment and examination of students, as well as award and revocation of degrees" the "welfare and discipline of students." ${ }^{43}$ The PAU Senate also receives recommendations on academic matters from the Boards of Institute - a quasi-governance organs at the Institute level-for consideration and approval if such recommendations fall within the matters over which the Senate has decision-making powers. A review of the roles of the PAU Senate shows that it has no business involving itself in strategy and financial management matters.

The PAU Senate comprises:

- The Rector;

- A representative of the Department in charge of Education within the [African Union] Commission;

- [The] Vice Rector for Academic and Students Affairs;

- [The] Vice Rector for Research, Development and Cooperation;

- [The] Director of Administration and Finance;

- The Deputy Vice Chancellor/Vice Rectors responsible for academic affairs at all host universities of PAU Institutes;

- The Directors of all PAU Institutes;

- One representative of the academic and research staff of each PAU Institute appointed by the PAU Council on the recommendation of the Rector; and

- One student representative from each PAU Institute appointed by the PAU Council on the recommendation of the Rector.

The PAU Senate is dominated by the administrative staff of both the PAU and the host universities of the PAU Institutes. Academic staff and students constitute $40 \%$ of the membership of the PAU Senate, with each stakeholder group accounting for $20 \%$ of the membership.

42 African Union Commission, "Revised Statute," 12.

${ }^{43}$ African Union Commission, "Revised Statute," 12. 


\section{IV.3.1.3. The Rectorate}

The Rectorate of the PAU comprises the Rector, the Vice Rector for Academic and Students Affairs, and the Vice Rector for Research, Development and Cooperation. The Rectorate is headed by the Rector who is, at the same time, the CEO of the PAU. The Rector is directly responsible to the PAU Council. The executive leaders at the Rectorate are appointed by the Chairperson of the African Union Commission on the recommendation of the PAU Council following a competitive process. The appointments run for five years and renewable once.

The Revised Statute demonstrates an attempt to strengthen the steering core of the PAU. The Rector has been granted authority over human resource matters but subject to certain checks and balances. A case in point is where the Statute empowers the Rector to "appoint all other staff of the Rectorate [except the Vice Rectors and the Director Administration and Finance] with the approval of the PAU Council." ${ }^{44}$ This resonates with the principle of letting the managers manage but also underscores the tension between empowerment and control.

The Statute assigns the performance management role of the Rector to the PAU Council. Therefore, the notion of performance contracting is explicit in the Statute. The executive leaders at the Rectorate are supposed to be evaluated annually by the PAU Council. The annual performance evaluations are preceded by annual performance contracts. The purpose of annual performance evaluations is to engender a high-performance culture and facilitate the achievement of the objectives of the PAU.

\section{IV.3.2. Institute-level management}

The thematic Institutes are the building blocks of the PAU. It is at the Institutes that teaching (and learning), research and innovation take place. Therefore, the Programme Departments and the Centres of the Institutes constitute the academic heartland of the PAU. Each Institute is headed by a Director who is responsible for the day-to-day management and administration of the Institute. The Director serves as a link between the Institute and the Rectorate. Each Institute is required to have a Board of the Institute comprising:

\footnotetext{
44 African Union Commission, “Revised Statute,"11.
} 
- A Vice Rector (Chairperson);

- The Director of the Institute (Secretary);

- Two Coordinators or Programme Departments within the Institute (on a rotational basis);

- The Coordinators of all Centres of the Institute (on a rotational basis);

- All full-time academic staff of the Institute;

- Two representatives of the Senate of the host country; and

- A representative of the thematic partners of the Institute (on a rotational basis).

The Board-- which is required to meet at least twice a year- is a 'quasigovernance' organ which is responsible for "the supervision of the academic, financial and administrative management of the institute." ${ }^{45}$ The Board is chaired by a Vice Rector, who is appointed by the Rector in consultation with the PAU Senate. The Board has no decision-making latitude but merely makes recommendations to the PAU Senate and the Rectorate depending on the body under whose jurisdiction the recommendation falls. The recommendations to the Rector are only in terms of appointment of nonprofessorial staff. On the other hand, the bulk of the work relates to making recommendations to the PAU Senate on matters such as the academic establishment of the Institute, student assessment reports, the promotion of teaching and research staff as well as programme-related matters.

\section{IV .4. Involvement of the host universities}

The Revised Statute describes the PAU as "a unitary academic, research and innovation Institution comprising thematic Institutes hosted in the five different geographical regions of Africa by existing academic institutions operating at graduate level." ${ }^{46}$ The essential elements in the description are theme, region and institutions. This begs the question: Do these attributes of the PAU have implications for the governance of the supranational university? A glimpse into the composition of the PAU Council, the PAU Senate and the Boards of Institutes depicts how the three attributes have been infused in varying degrees into some of the governance and management organs of the PAU. The only organ in which they have not been entrenched is the Rectorate

\footnotetext{
45 African Union Commission, "Revised Statute," 17.
}

${ }^{46}$ African Union Commission, "Revised Statute," 6. 
owing to the imperative to create a dividing line between governance and management.

Unlike the regional economic communities and the thematic partners, the host universities are represented on the PAU Senate. Again, the host institutions and the thematic partners converge on the Boards of Institutes. However, the point to note is that the host universities have de jure representation in the unicameral model which assign the PAU Council the oversight and the PAU Senate a heavily advisory role to the PAU Council. Similarly, the host university is represented on the Boards of Institutes which exercise a supervisory role over the PAU Institutes in the different geographical locations. Therefore, the host universities are involved in governance at the PAU Council, the PAU Senate and at Boards of Institute. At the Council level, the Vice Chancellors/Rectors of the host universities of the PAU Institutes are members of the PAU Council. On the other hand, the Deputy Vice Chancellors/Deputy Rectors responsible for academic affairs at all the host universities are members of the PAU Senate.

The presence of the host universities at all the levels can be explained by the convergence in the missions of the PAU and the host universities, and the imperative to strengthen synergy between the two universities. Another explanatory factor is the nature of the academic awards. The Statute states that "[d]egrees shall be jointly awarded by the PAU and the host institutions" ${ }^{47}$ and this necessitates participation of the host universities in the oversight organs.

\section{IV.5. Merit-based selection}

Merit is the guiding principle for appointment to academic, administrative, technical and support positions at the PAU. The Revised Statute stipulates that "the basic criteria for selection [of staff] shall be the highest standards of qualification, competence, efficiency and integrity." 48 In addition to the statutory provision above, there are other explicit indicators of the merit principle. First, appointments to executive leadership positions are effected after a competitive selection process. Therefore, election by the Council, open competitive electioneering, election by the peers and handpicking by certain actors are unacceptable means of assumption of office at the PAU. Even for positions for which the Rector is empowered to appoint staff, there

\footnotetext{
47 African Union Commission, "Revised Statute," 24.

48 African Union Commission, "Revised Statute," 20.
} 
is provision for consulting the PAU Council before such appointments are effected. This indirectly assigns veto powers to the PAU in instances where merit might have been compromised during the recruitment and selection processes.

There is a nexus between merit and the performance of an institution. Viewed from the perspective of education, the quality of education can rise above the quality of the teachers. Within the open system thinking, the quality of staff - especially the quality of academic staff- influences the quality of the outputs in terms of the graduates, research and innovations. Considering the demanding objectives of the PAU in the domain of research, teaching and innovation, it is unlikely that merit would take a backseat during recruitment and selection. Similarly, the PAU has set out to nurture quality and exemplify excellence as well as become a world-class University. These aspirations demand that attention is paid to the quality of staff.

\section{Discussion and conclusions}

The article has described the governance architecture of the PAU within the context of a supranational higher education institution. The PAU is a brainchild of a political grouping- the African Union - to achieve the political, social and economic ends of the Union. It exemplifies the commitment of the political leadership at the highest echelons to address the endemic challenges confronting the continent through higher education. Therefore, the governance and management of the PAU cannot be insulated from the politics of the time. The Assembly, both directly and through other political organs, such as the Executive Committee and the AUC, remotely steer the University. Despite being at a distance, these remote actors wield considerable power over important decisions save for purely academic questions and matters at the student-academic interface. The leadership of the PAU Council is appointed by the supranational body and is, therefore, likely to steer the activities of the PAU towards the AU agenda.

The principal governance organs of the PAU are the University Council, the Senate and the Rectorate or the executive leadership arm. There is a convergence in the governance organs of the PAU with the principal governance organs of universities in African countries, ${ }^{49}$ similar to those in

49 Ebrima Sall and Ibrahim Oanda, "Revitalising higher education for Africa's future," JHEA/RESA 12, no.2 (2014): 102-104. 
the United Kingdom, ${ }^{50}$ Australia, ${ }^{51}$ and Uganda. ${ }^{52}$ The parallel in the main governance organs can be rationalised by the convergence in the missions of universities. There is another convergence of the findings with the governance trends in continental Europe, Australia and the United States. Specifically, the subordination of the Senate to the Rector, relegation of the Senate to an advisory role and strengthening the executive arm of the university are in sync with the higher education developments in continental Europe and in Australia. ${ }^{53}$ In terms of strengthening the Rectorate, the Rector of the PAU has been empowered to appoint all staff in the Rectorate, save the Vice Rectors, in consultation with the University Council. This is consistent with the private sector practices which emphasise accountability for results and advocate the delegation of staffing authority to the chief executives. This is intended to guard against the tendency by the CEOs to attribute the nonachievement of results to the quality of staff appointed by other organs.

In some cases, the findings deviate from the findings in the previous studies on university governance. The previous studies point to the idea that the university senates are dominated by academics. The findings in this study point to the contrary. The Senate of the PAU is lay-dominated. The small number of academics in the Senate could be as a result of the representational mode of membership by the Directors of the PAU Institutes. Secondly, it could be due to the desire not to involve academics in academic governance beyond their thematic area around which the Institute is organised. Therefore, academics can participate in academic governance at Institute level. Secondly, reforms in university governance, and the practices in Australia and continental Europe, point to a shift to small and lay-dominated University Councils. Whereas the PAU Council is lay-dominated, the number of members is 30 compared to a maximum of 15 members that was reported by studies in continental Europe and Australia. The huge number can be explained by the nature of the PAU. As a continental university, the PAU should take care of the huge number of stakeholders for it to have a continental outlook.

A noteworthy finding is that, in addition to the principal governance organs of the PAU, the Institutes have 'quasi-governance bodies'- or Boards of Institutes-which are charged with oversight of the academic, administrative

${ }^{50}$ Shattock, “University governance, leadership and management," 222-228.

${ }_{51}$ Rowlands, Academic governance.

${ }^{52}$ Lazarus Nabaho, "Shared governance in public universities in Uganda: Current concerns and directions for reform," International Journal of African Higher Education 5, no.1 (2019): 61 .

${ }^{53}$ Rowland, "Academic governance." 
and management affairs of the Institutes. The Boards comprise both internal and lay stakeholders. This organ is a variant and does not exist in universities at national level. As already stated, the Board is chaired by a Vice Rector who is appointed by the Rector. The purpose of this organ could have been to bring the Rectorate's oversight role closer to the Institutes and to place the oversight role of the Institutes in the hands of the stakeholders who are based within the region. Finally, it could have been intended to compensate for the limited participation of academics in governance at the macro- or universitylevel organs such as the PAU Council and the PAU Senate. As we have noted earlier, the PAU Senate is lay-dominated in contrast to the composition of the senates at national level. It is, therefore, not surprising that the oversight functions which have an academic element outnumber those with an administrative and managerial component.

In view of the findings, it can be inferred that the governance landscape of a university is influenced by the context. Therefore, while there is a convergence in the form of governance organs, the substance of these governance organs varies considerably across contexts. The PAU has revealed governance dynamics which are unique to its nature as a supranational institution. Therefore, a common template or a one size-fits-all governance arrangement for universities is untenable. Finally, the governance arrangements by the States and supranational bodies are a means to an end. In other words, they are aimed at steering universities to contribute to societal needs.

The study contributes to the university governance literature and practice by providing perspectives from a supranational university as a new entrant in the global higher education landscape and discourse. The findings provide insights which may be contextualised in national higher education spaces with a view to enhancing governance. Finally, the article has examined the provisions of the Revised Statute of the PAU from a scholarly point of view. Therefore, we have extended the discourse from 'what the Revised Statute stipulates' as is the case at the moment to 'what it stipulates, why it stipulates it, and the implications of what it stipulates' for university governance in particular and higher education in general.

The article used the Revised Statute as the sole data collection document. Therefore, the findings lean more towards what should be rather than what is. In the governance discourse regulatory frameworks can reflect political symbolism, hence creating a gap between statutory provisions and practice. In view of this limitation, we recommend that studies focus on the PAU's compliance with governance provisions in the Revised Statute and the effectiveness of such a governance system. 


\section{Bibliography}

African Union Commission. Second Decade of Education for Africa (2006-2015) Plan. Addis Ababa: AUC, 2006.

- - - . Agenda 2063: First Ten-Year Implementation Plan 2014-2023. Addis Ababa: AUC, 2015.

- - - Agenda 2063: The Africa We Want. Addis Ababa: AUC, 2015.

- - - Revised Statute of the Pan African University. Addis Ababa: AUC, 2016.

Birnbaum, Robert. "The end of shared governance: Looking ahead or looking back." New Directions for Higher Education 127(2004):1-22.

Bleiklie, Ivar. "Collegiality and hierarchy: Coordinating principles in higher education," in The global university: Past, present and future perspectives, edited by A. R. Nelson \& I. P. Wei, 85-104 (New York, NY: Palgrave Macmillan, 2012)

Donina, Davide, and Sandra Hasanefendic. "Higher education institutional governance reforms in the Netherlands, Portugal and Italy: A policy translation perspective addressing the homogeneous/heterogeneous dilemma." Higher Education Quarterly 73 (2019): 29-44. https://doi.org/10.1111/hequ.12183.

Duderstadt, J. James. "Governing the twenty-first century university: A view from the bridge." (2002). Retrieved April 1, 2020 from milproj.ummu. umich.edu/ publications/view_from_bridge/.../view_from_bridge.pdf.

Hénard, Fabrice, and Alexander Mitterle. Governing and quality guidelines in higher education: A review of governance arrangements and quality assurance guidelines. Paris: OECD, 2009.

Gornitzka, Åse, Peter Maassen, and Harry de Boer. "Change in university governance structures in continental Europe. "Higher Education Quarterly 71(2017): 27489. https://doi.org/10.1111/hequ.12127.

Jessop, Bob. "The rise of governance and the risks of failure: The case of economic development." International Social Science Journal 155 (1998):29-45. https:// onlinelibrary.wiley.com/doi/pdf/10.1111/1468-2451.00107.

Harman, Kay, and Elaine Treadgold. "Changing patterns of governance for Australian universities." Higher Education Research \& Development 26, no.1 (2007): 1329. DOI: 10.1080/07294360601166786.

Kennedy, Kerry J. "Higher Education governance as a key policy issue in the $21^{\text {st }}$ century." Educational Research for Policy and Practice 2, no.1 (2003): 55-67. https://doi.org/10.1023/A:1024468018883.

Krippendorff, Klaus. Content analysis: An introduction to its methodology. 2nd ed. Thousand Oaks: Sage, 2004.

Lokuwaduge, Chitra, and Anona Armstrong. "The impact of governance on the performance of the higher education sector in Australia." Education Management, Administration and Leadership 43, no.5 (2014): 811-27. https://doi. org/10.1177\%2F1741143214535740.

Marginson, Simon, and Mark Considine. The enterprise university. Melbourne: Cambridge University Press, 2000. 
Moodie, Graeme, and Rowland Eustace B.Power and authority in British universities. London: Allen and Unwin, 1974.

Nabaho, Lazarus. "Shared governance in public universities in Uganda: Current concerns and directions for reform." International Journal of African Higher Education 5, no.1 (2019): 45-65. https://doi.org/10.6017/ijahe.v5i1.10962.

Nabaho, Lazarus, Wilberforce Turyasingura, Alfred K. Kiiza, Felix Andama, and Adrian Beinebyabo. "Quality Assurance of Higher Education Governance and Management: An Exploration of the Minimum Imperative for the Envisioned African Common Higher Education Space." Higher Learning Research Communications 10, no.2 (2020): 38-52.

DOI:10.18870/hlrc. v10i2.1183.

Neave, Guy. "The Evaluative State Reconsidered." European Journal of Education 33, no.3 (1998): 265-84. https://www.jstor.org/stable/1503583.

- - _ . "Governance, power and coordination." IAU Horizons 12, no.1 (2006).

Núñez, Javier, and Benjamin Leiva. "The effects of a tripartite 'participative' university senate on university governance: The case of the University of Chile." Cambridge Journal of Education 48, no.6 (2018): 749-67. https://doi.org/10.10 80/0305764X.2017.1418832.

OECD.OECD thematic review of tertiary education (2008).

O'Malley, Brendan. "First 17 European universities' alliances announced." University World News, 27 June 2019.

Pan African University, Strategic Plan (2020-2024) Yaoundé: PAU, 2020.

Pennock, Lea, Glen A. Jones, Jeff M. Leclerc, and Sharon Li X. "Challenges and opportunities for collegial governance at Canadian universities: Reflections on a survey of academic senates." Canadian Journal of Higher Education 46, no.3 (2016): 73-89.

Rowlands, Julie. Academic governance in the contemporary university: Perspectives from Anglophone nations (Singapore: Springer, 2017).

Saint, William. "Guiding Universities: Governance and Management Arrangements Around the Globe" (2009).Available at: https://teqipgoodgovernance.in/pdf/ University-Governance-and-Management-FINAL-Revised-2-Feb-2010.pdf.

Sall, Ebrima, and Ibrahim Oanda. "Revitalising higher education for Africa's future." JHEA/RESA 12, no.2 (2014): 95-107.

Shattock, Michael. Managing good governance in higher education. Maidenhead: Open University Press, 2006.

- - - . "University governance, leadership and management in a decade of diversification and uncertainty." Higher Education Quarterly 67, no.3 (2013): 217-33. https://onlinelibrary.wiley.com/doi/abs/10.1111/hequ.12017.

- _ - "The context of 'modernising' reforms in university governance." In International trends in university governance, edited by Michael Shattock, 1-14. Oxford: Routledge, 2014.

- - - . "University governance, leadership and management in a decade of diversification and uncertainty." Higher Education Quarterly 67 (2017): 217-33. doi:10.1111/hequ.12017. 
Taylor, Mark. "Shared governance in the modern university." Higher Education Quarterly 67, no.1 (2013): 80-94. https://doi.org/10.1111/hequ.12003.

Toma, J. Douglas. "Expanding peripheral activities, increasing accountability demands and reconsidering governance in US higher education." Higher Education Research and Development 26, no.1 (2007): 57-72. https://doi. org/10.1080/07294360601166810.

United Nations Information Service (USIS). "Information technology should be used to tap knowledge from greatest universities to bring learning to all, Kofi Annan says.” Published August 2, 2000. Accessed $3^{\text {rd }}$ February 2020. https://www. un.org/press/en/2000/20000802. sgsm7502.doc.html.

World Bank. Higher education in developing countries: Peril and promise. Washington, DC: The World Bank, 2000.

\section{About the authors}

LAZARUS NABAHO (lnabaho@umi.ac.ug) is a Senior Lecturer and the Head of the Department of Government Studies at Uganda Management Institute. He holds a Doctor of Philosophy in Education Management of Makerere University, Uganda. His research interests include quality assurance in higher education, higher education governance, and teaching and learning in higher education. Nabaho is the Chief Editor of The Ugandan Journal of Management and Public Policy Studies (UJMPPS), a reviewer of several academic journals, and an external examiner at several universities.

WILBERFORCE TURYASINGURA (wturyasingura@umi.ac.ug) is the Dean of the School of Business and Management at Uganda Management Institute. He holds a $\mathrm{PhD}$ in Management from Wits University, South Africa. His research interests include knowledge management, performance management, strategic management, and human resource development.

JESSICA NORAH AGUTI (aguti@cees.mak.ac.ug) an Associate Professor in the Institute of Open, Distance \& e Learning, Makerere University but was recently on secondment at the Commonwealth of Learning (COL) as an Education Specialist, Teacher Education. She hold a $\mathrm{PhD}$ in Curriculum Instruction and Teaching of the University of Pretoria, South Africa. Her research areas are open and distance (e) learning, curriculum, teaching and learning, and quality assurance in higher education. She has been teaching at Makerere University for the last 27 years.

FELIX ADIBURU ANDAMA (fandama@umi.ac.ug) is a Consultant in Government Studies at Uganda Management Institute. He holds a PhD in Governance and Public Sector Management of North West University, South Africa. His research areas are decentralisation and local governance, public policy, and governance. Felix has been teaching at Uganda Management Institute since 2008. 


\title{
Understanding the governance dynamics of a supranational university: The African pioneering model
}

\author{
Lazarus Nabaho, Wilberforce Turyasingura, Jessica Norah Aguti, \\ and Felix Adiburu Andama
}

doi: http://dx.doi.org/10.18543/tjhe-8(1)-2020pp27-52

\section{Copyright}

Copyright for this article is retained by the Publisher. It is an Open Access material that is free for full online access, download, storage, distribution, and or reuse in any medium only for noncommercial purposes and in compliance with any applicable copyright legislation, without prior permission from the Publisher or the author(s). In any case, proper acknowledgement of the original publication source must be made and any changes to the original work must be indicated clearly and in a manner that does not suggest the author's and or Publisher's endorsement whatsoever. Any other use of its content in any medium or format, now known or developed in the future, requires prior written permission of the copyright holder. 